\title{
Preparing a Local Hazard Mitigation Plan: A Case Study in Watsonville, CA
}

\author{
Emily Lipoma \\ MCRP Cal Poly (2012); planner, City of San Jose.
}

Centered just twelve miles outside the City of Watsonville, the 7.1 magnitude Loma Prieta earthquake hit Santa Cruz County in 1989, causing extensive damage. Community vulnerability to natural disasters can be reduced by incorporating hazard mitigation into mainstream land use planning processes. In this article, Emily Lipoma discusses her professional project for her MCRP in 2012, a Local Hazard Mitigation Plan for Watsonville.

F rom October 26th to November 8th, 2012, Hurricane Sandy impacted millions of people as the hurricane caused flooding and power outages through 16 states. Approximately 380,000 homes were destroyed or damaged and the cost of recovery is estimated at over $\$ 70$ billion. From June 5th to June 16th, 2004, wildfire tore through 7,500 acres of Santa Barbara County, threatening two oil refineries and 200 homes. These disasters and many others like them can cause deaths and devastate a town, region, or state in minutes or even seconds and take years of rebuilding.

The severity of the impact is not only related to the intensity of the event (the magnitude of the event or the geographic extent of the affected area), but it is also related to the vulnerability of the community it affects. Complete protection from every potential natural or human-caused hazard is unlikely, but measures can be taken to prepare a community to respond and recover from a hazardous event and reduce the severity of future hazard impacts. Several authors suggest that community vulnerability to disaster can be reduced through appropriate land use management and by incorporating hazard mitigation into mainstream land use planning processes. In this context, mitigation is commonly defined as taking sustained actions in community planning to reduce long-term risks to populations and property from hazards (Schwab 2010, Schwab et al 1998).

Hazard mitigation for a community can be undertaken by a number of different parties, although it is commonplace for planning departments to develop Hazard Mitigation Plans, either through incorporation into a General Plan or other long-range community guiding document, or as a standalone Hazard Mitigation Plan. Developing a Local Hazard Mitigation Plan allows communities and stakeholders to identify and incorporate appropriate strategies to reduce the vulnerability of a locality. Objectives of such a plan include identifying vulnerable buildings and infrastructure, programming needed improvements into government budget priorities, and persuading private property owners to undertake similar commitments (Schwab et al 1998). Additionally, cities with completed Local Hazard Mitigation Plans are eligible to receive additional federal and state funding to rebuild affected areas.

In 1988 the federal government established the Stafford Act, which established an emergency response and preparedness system: individuals and households can receive basic disaster relief, and jurisdictions can receive post-disaster infrastructure restoration grants and hazard mitigation grants to prevent repetitive losses. As time went on, it was found that programs encouraging mitigation reduced the amount of federal relief and recovery funds paid to states and localities after a disaster event: for every $\$ 1$ invested in mitigation, \$4 of disaster losses are avoided. The Disaster Mitigation Act of 2000 (DMA 2000) further worked toward the goal of reducing risk before an event; the program is intended to reduce preventable, repetitive losses from disasters.

However, eligibility for DMA 2000 grants requires a MultiHazard Mitigation Plan as a precondition for federal mitigation project grants. DMA 2000 encourages state and local mitigation projects through financial incentives and competitive applications. Through incentives to encourage better development and planning decisions at the state and local levels, hazards can be mitigated before a hazard event (Topping 2011).

\section{The City}

The City of Watsonville is located in Santa Cruz County within coastal California and has a population of 51,199 (2010 Census). The city is approximately 6.6 square miles and includes a prominent slough system within the city limits. The area has a strong agriculture-based economy and the city economy is closely associated with 
the agricultural activities of the larger area. In 1989, a 7.1 magnitude earthquake hit Santa Cruz County at 5:07 p.m. on October 17. The Loma Prieta Earthquake, centered 12 miles outside of Watsonville, caused extensive damage throughout the county from the initial earthquake and from the 7,500 subsequent aftershocks which ranged from 1.0 to 5.4 magnitude over the next two years. There were 63 earthquake-related deaths (5 of which were in Santa Cruz County), and more than 3,700 injuries.

Although the Loma Prieta earthquake affected a large region, based on the damage Santa Cruz County was clearly the hardest-hit area. Of the 988 homes destroyed, 744 were in Santa Cruz County, and of the 23,408 homes damaged, 13,329 were in Santa Cruz County. Of the 366 businesses destroyed and 3,495 businesses damaged due to the earthquake, 310 businesses and 1,615 businesses respectively were in Santa Cruz County (Schwab, et al 1998).

In addition to the pure number of homes and businesses affected, "damage was particularly acute for the cities of Santa Cruz and Watsonville because the damage was concentrated in the downtown areas vital to the commercial, residential, and social/cultural identity of the communities" (Schwab, et al 1998). Watsonville sustained an estimated $\$ 200,000$ to $\$ 250,000$ in sales tax losses in the years directly following the earthquake. In downtown Watsonville, 22 buildings were demolished, creating a loss of almost $700,000 \mathrm{sq} f t$ of retail space. Approximately $90 \%$ of the damage in the city was due to unreinforced masonry buildings and wood-frame structures that were not properly fastened to their foundation. Watsonville is built on soils that have a moderate to high potential for liquefaction, lateral spreading, and subsidence; and is built on areas with a potential for landslides. Most of the Loma Prieta Earthquake damage in the city was at locations where the soils liquefied.

After the initial earthquake, aftershocks in Watsonville brought the possibility of additional damage. Tremors hit the primarily Latino residential areas near downtown

Figure 1: Damage to St. Patrick's Church in downtown Watsonville after the Loma Prieta Earthquake. (Robert A. Eplett/CAL EMA)

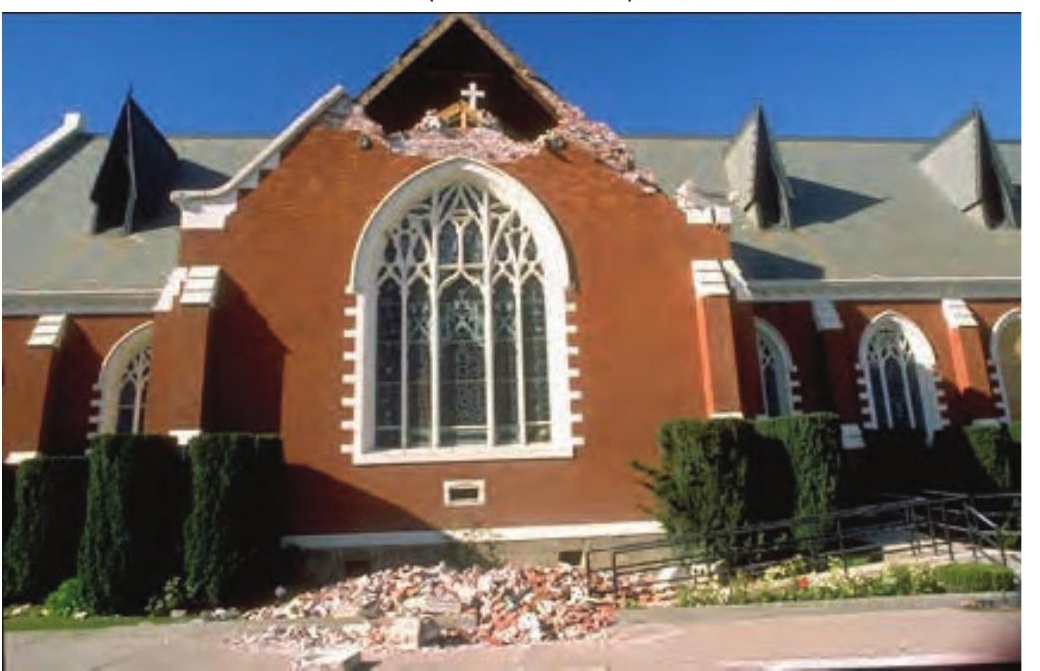

particularly severely and 550 residences were yellowtagged (damage-limited entry) and 406 were red-tagged (major damage). An initial 1,500 people were homeless and many refused to enter buildings (including officially designated shelters) because of knowledge of the significant casualties caused by aftershocks in the earlier Mexico City earthquake. Language barriers further complicated relief and recovery efforts (Schwab, et al 1998).

The initial temblor destabilized many buildings, ruptured natural gas lines, and disrupted water supply infrastructure. Subsequently, fires broke out from natural gas leaks, and the inaccessible water supply paralyzed the effort to put out the fires. This synergistic effect of a multi-hazard event underscores the necessity of not only addressing individual hazards, but what could happen if other hazards were triggered at the same time. The Loma Prieta Earthquake also damaged the levees that protect the city from flooding. Had this major earthquake occurred later in the season when the water level was higher, significant flooding could have occurred as well, further damaging the city and hindering emergency response and recovery efforts.

In addition to being located in a seismically active area, flooding and human-made hazards are also a risk to the City of Watsonville. Watsonville is bordered to the north and east by the Corralitos and Salsipuedes creeks and the Pajaro River, and there are substantial slough areas throughout the city. There are currently 11.5 miles of levees along the Pajaro River and 3 miles of levees along the Salsipuedes Creek protecting the city from flooding. The existing channel and levee system along the Pajaro River has approximately a 15-year storm capacity. The Corralitos and Salsipuedes Creeks have five- and seven-year storm capacities respectively. Substantial flooding has occurred most recently along these waterways in 1995 and 1998.

In 1995 the Pajaro River and Corralitos Creek overflowed and flooded 3,280 acres. Agricultural crop damages

Figure 2: Damage to Highway 1 near Watsonville after the Loma Prieta Earthquake. Extensive damage to this critical roadway severely impacted earthquake recovery. (J.C. Tinsley, United States Geological Survey) 
were estimated at $\$ 67$ million and in the unincorporated town of Pajaro in Monterey (across the Pajaro River from Watsonville), damages were estimated at $\$ 28$ million. In $1998,1,100$ acres were flooded and approximately $\$ 1.7$ million in agricultural crop damages and \$ 0.4 million in non-crop damages occurred. These agricultural damages are considered to be low, because 800 of the 1,100 flooded acres were in the preparation phase and without established plantings.

In addition to the risk of economic loss around the city, several critical facilities within the City of Watsonville are within the 100-year floodplain. These facilities include the civic plaza, police headquarters, and a fire station, as well as several water pumping facilities. If shallow flooding does not exclude use of these facilities, it may impact their use and hinder city operations and emergency response.

Levees protecting Watsonville are owned by the City, but are managed by the County. The inter-jurisdictional nature of the Pajaro River (it establishes the county line between Santa Cruz and Monterey counties and is a part of a watershed that extends into San Benito and Santa Clara counties) requires many stakeholders in the decisionmaking process regarding the Pajaro River and its levees. The City has undertaken minor channel maintenance activities and levee studies, and the County and watershed joint agency have initiated studies and plans for major levee improvements and flood control projects. However, funding for the completion of the projects is lacking, and the City is not the primary decision-maker for major levee projects to increase the flood protection for the city.

The city is surrounded by farmland, and within the city there are many cold storage and pesticide facilities that require the use of hazardous materials. Currently, approximately $95 \%$ of the acutely or extremely hazardous material locations in the county are in Watsonville (County of Santa Cruz, 2009). During the Loma Prieta Earthquake there were a number of significant hazardous material spills, although they were primarily incidents where smaller amounts of materials were released and mixed. Larger amounts of hazardous materials were properly secured. The amount of hazardous materials in the city presents a continuing risk and previous releases underscore the potential for future events.

Watsonville is also at risk of several other hazards: Although wildfire risk has decreased with urban development, the severity of urban fires is increased due to older building stock and a dense population. Two of the past seven significant urban fire events in the city have occurred in structures that house vulnerable populations: The Wall Street Inn fire in 2005 displaced 50 elderly residents when a 94-year-old residential hotel caught fire, and the Stag Hotel fire in 2012 displaced 50 low-income residents from an 85-year-old residential hotel. These buildings and populations are equally vulnerable to an earthquake.

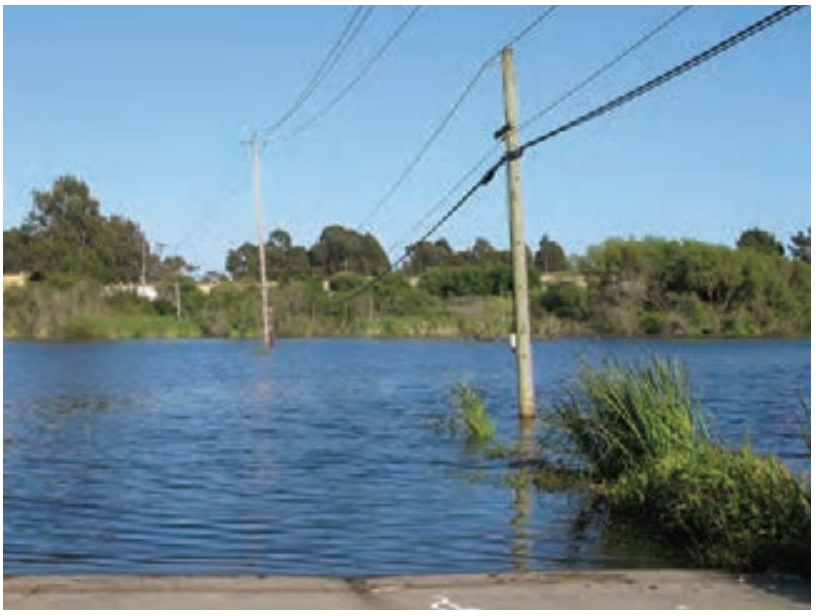

Figure 3: Repeated flooding of the sloughs has reclaimed Harkins Slough Road. (Emily Lipoma)

\section{The Project}

The City of Watsonville was approached in the fall of 2011 to be the subject for a Local Hazard Mitigation Plan for a masters professional project at Cal Poly San Luis Obispo (Lipoma, 2012). Watsonville was identified as a suitable city because the city did not have a LHMP nor immediate plans to create one. There had initially been plans for a joint-LHMP between the county and the four cities within the county; however, it was not completed. There are several City-owned facilities that are non-contiguous to the main city limits: the wastewater treatment plant, city landfill, Pinto Lake (a city park), and water facilities. Additionally, the city water district and emergency response facilities serve county residents outside of the city and infrastructure for these city facilities extends outside of the City's jurisdiction.

Initial response to the project proposal was supportive, yet skeptical. There were several aspects which allowed a student to undertake the project in coordination with the City. A Local Hazard Mitigation Plan had been on the drawing board for several years, but no funding had been allocated, and no action had been taken to initiate it. Thus key city staff had already recognized that such a plan would be beneficial to the city, but because such a plan had not yet been undertaken, the proposed project would not interfere with existing city projects. Furthermore, any progress that the proposed project made toward a Local Hazard Mitigation Plan would not require city funding. The final, and the most compelling, selling point to the city was that adopting an LHMP would make the City eligible for both mitigation and recovery grants for which they were not already eligible.

Local Hazard Mitigation Plans are commonly integrated into the Safety Element of a locality's General Plan, and there are state funding incentives to do so. However, the 2005 City of Watsonville General Plan update was 
upon the expertise of the assembled Hazard Mitigation Advisory Team. Unfortunately, the team was not ready to develop mitigation actions for the identified risks within the timeline for completing the academic project. The project scope was then modified to exclude completion of the mitigation strategy, and steps and actions were identified for the City to consider when developing a mitigation strategy independent of the academic project.

Once the academic objective of the project was completed, the City decided to complete the project while there was still momentum to do so. The Public Works Department is overseeing and funding the completion of the project, which requires the completion of a mitigation and implementation strategy, a cost analysis, public review, and adoption of the plan by the City Council.

\section{Completing the Project}

Completion of the project is underway. Mitigation measures are being developed by small groups of city staff members who are most knowledgeable about the hazard and who have control regarding implementation of the actions. Descriptions of each mitigation action include: whether the action is a very high, high, or an important priority; whether the action has a high, medium, or low cost and benefit; which lead department will be responsible for implementation; what the timeline of the action is; what resources are required for implementation; where any funding will be derived from; and how each action will be incorporated into city operation. This additional information will inform the implementation strategy.

Most of the mitigation actions in the mitigation strategy are being developed specifically by the city staff members who will be carrying the actions out. In this way, the mitigation actions are for the LHMP but initiative for their completion will be from the departments responsible for their implementation. It is likely that mitigation actions identified for the LHMP will be implemented as a department action rather than specifically as something that is for the LHMP.

While developing the mitigation strategy, it was found that there were several simple actions that could be done to reduce the vulnerability of the city-essentially lowhanging fruit (Lipoma, 2012). The risk assessment identified and examined risk to the extent possible, but to further understand hazards such as urban fire, subsidence, and aircraft collisions to a greater depth, more data is required. For instance, loss of life in urban fires can be reduced by identifying high-risk structures and particularly vulnerable populations (such as senior care and high-occupancy facilities) and ensuring they are equipped with fire alarms and fire suppression equipment.

In other cases additional communication and cooperation between different agencies is needed. Hazardous materials are regulated by Santa Cruz County; communication and cooperation between the County and City on the location, amount, and type of hazardous materials within the city are critical for guiding city-specific hazardous materials safety requirements. These actions require little additional funding and can be completed with existing staff resources, can have a large benefit, and can initiate momentum for completing larger and more costly mitigation projects.

Once all aspects of the plan are complete an administrative draft will be reviewed by city departments, neighboring communities, other government agencies, and the Red Cross. Action Pajaro Valley, a community action organization, will be invited to review the administrative draft as well. Any edits or comments will be incorporated into the draft before a final draft is presented to the City Council for adoption. Once the plan is either adopted or adopted with the condition of approval, it will be sent to the State and FEMA for review.

Implementation of the Watsonville Local Hazard Mitigation Plan will depend on a few factors: a champion to ensure implementation and incorporation of the identified mitigation measures into city department plans. Charles Eadie writes that "hazard mitigation works best as a policy objective of local planning when it is so completely integrated into the comprehensive plan that it becomes a normal assumption behind all daily planning activities" (Schwab, et al 1998). While hazard mitigation planning in Watsonville has not likely reached "complete integration" with all normal planning activities, it is certainly much closer to achieving that objective.

\section{References}

Burby, Raymond J. (ed.). 1998. Cooperating with Nature: Confronting Natural Hazards with Land-Use Planning for Sustainable Communities. Washington D.C.: Joseph Henry Press.

Federal Emergency Management Agency. 2002. How To Guide \#1 - Getting Started: Building Support for Mitigation Planning (FEMA 386-1).

Federal Emergency Management Agency. 2004. News Release: FEMA Quickly Makes Funds Available for Gaviota Fire.

Lipoma, Emily. 2012. City of Watsonville Local Hazard Mitigation Plan. MCRP thesis. CRP Department, Cal Poly State University San Luis Obispo.

Mileti, Dennis. 1999. Disasters by Design. Washington D.C.: Joseph Henry Press.

Newman, A. 2012. Hurricane Sandy vs. Hurricane Katrina. In New York Times. http://cityroom. blogs.nytimes. 
com/2012/11/27/hurricane-sandy-vs-hurricane-katrina/?_r=0; access on November 27, 2012.

Santa Cruz County Government. 2009. Hazardous Materials Area Plan. Santa Cruz, California.

Schwab, Jim et al. 1998. Planning for Post-Disaster Recovery and Reconstruction. Planning Advisory Service Report 483/484. Chicago: American Planning Association / FEMA.

Schwab, James (ed.). 2010. Hazard Mitigation: Integrating Best Practices into Planning. Planning Advisory Service Report 560. Chicago: American Planning Association.

Topping, Ken C. 2011. Federal and State Laws and Systems [from Cal Poly class notes].

U.S. Census Bureau. 2010. Profile of General Population and Housing Characteristics: 2010. 2010 Demographic Profile Data. 